\title{
Modulation by photoperiod of gonadotrophin secretion in intact and castrated Djungarian hamsters
}

\author{
S. M. Simpson, B. K. Follett and D. H. Ellis \\ A.R.C. Research Group on Photoperiodism \& Reproduction, Department of Zoology, \\ The University, Bristol BS8 IUG, U.K.
}

\begin{abstract}
Summary. Reproductive activity in the Djungarian hamster, Phodopus sungorus, is suppressed by short daylengths and induced and maintained by long daylengths. To determine the time course of changes in plasma and pituitary gonadotrophin concentrations during the photoperiodic response, sexually immature male hamsters were moved from short (9L:15D) to long days (14D:10D). This induced an increase in testicular weight in 5 days and full sexual maturity in about 1 month. Plasma and pituitary FSH concentrations were significantly elevated after 3 and 5 long days respectively, reaching peak levels after 7-14 days and then declining. In contrast, pituitary and plasma LH concentrations did not increase until 10 and 21 days of photostimulation respectively.

Castration of hamsters kept in short days led to a marked increase in plasma and pituitary FSH titres. Transfer to long days further increased plasma FSH although pituitary content did not change. Castration of hamsters kept in long days led to an elevation of plasma and pituitary FSH concentration to these same levels. Transfer to short days reduced plasma FSH to the levels seen in hamsters castrated and kept in short days. Pituitary content did not change. The results suggest that while there is substantial steroid negative feedback in intact animals on both long and short days, the photoperiodic modulation of gonadotrophin secretion does not necessarily involve changes in feedback sensitivity.
\end{abstract}

\section{Introduction}

Reproductive activity in the Djungarian hamster, Phodopus sungorus, is strongly influenced by photoperiod, the gonads maturing under long daylengths and regressing when the daylength is short, either under natural lighting or following artificial photoperiodic manipulation (Figala, Hoffmann \& Goldau, 1973; Hoffmann, 1973, 1974, 1978; Hoffmann \& Küderling, 1975, 1977). In contrast to juvenile golden hamsters in which the testes become fully developed regardless of the photoperiod (Gaston \& Menaker, 1967), the neonatal Djungarian hamster is photoperiodically responsive, males raised from birth in long days developing large testes and showing full spermatogenesis from 31 days of age, while those reared in short days remain sexually immature until spontaneous gonadal development begins at about 130 days of age (Hoffmann, 1978; Yellon \& Goldman, 1980). Photoperiodic time-measurement is most probably effected through a circadian clock and within the photoneuroendocrine axis the pineal gland plays a central role (Hoffmann, 1973, 1974, 1981; Hoffmann \& Küderling, 1977; Brackmann \& Hoffmann, 1977). The value of Djungarian hamsters for studying both the photoperiodic clock and its interaction with pineal function would be greatly enhanced were it 
possible to detect changes in gonadotrophin secretion very soon after photostimulation, a possibility exploited so far only in the Japanese quail (Follett, Davies \& Gledhill, 1977). The first aim of the present investigation was, therefore, to measure the basic pattern of change in luteinizing hormone ( $\mathrm{LH})$ and follicle-stimulating hormone (FSH) after photostimulation of somatically mature male hamsters first rendered sexually quiescent by exposure to short days.

The hypothesis that during the photoperiodic response there is a change in the sensitivity of the hypothalamo-pituitary axis to feedback from gonadal steroids, and that this is an important component in the alteration of gonadotrophin secretion, has gained its strongest support from the observation that ovariectomized Suffolk ewes, castrated stags and, in certain circumstances, castrated golden hamsters fail to show marked changes in mean levels of plasma gonadotrophins in response to photoperiodic switches, and that gonadal steroids exert a more effective negative feedback outside the breeding season (Legan, Karsch \& Foster, 1977; Turek, 1977; Lincoln \& Kay, 1979; Ellis \& Turek, 1979; Goodman \& Karsch, 1980). In several other species, however, the presence of sex steroids is not mandatory for the expression of photoperiodic changes in gonadotrophin output, and a change in the response to sex steroids in such animals is not believed to be a crucial regulator of hypothalamo-pituitary activity. One of the best examples is the Japanese quail (Gibson, Follett \& Gledhill, 1975; Urbanski \& Follett, 1982) but data also come from hares, mares, rams and golden hamsters (Davies \& Meyer, 1973; Pelletier \& Ortavant, 1975; Turek, Elliott, Alvis \& Menaker, 1975; Freedman, Garcia \& Ginther, 1979; Lincoln \& Short, 1980; Urbanski \& Simpson, 1982). The variability seen in the photoperiodic responses of gonadectomized animals and the present arguments over the relative importance of changes in steroid feedback suggested that the matter needed investigation in the Djungarian hamster.

\section{Materials and Methods}

Djungarian hamsters were bred from our colony which is held in long days ( $14 \mathrm{~h}$ light:10 $\mathrm{h}$ dark, lights on 08:00-22:00 h), and either kept in long days or transferred at birth to short days (9L:15D, lights on 08:00-17:00 h). They were weaned and sexed when 20-30 days old and the males were housed in groups of up to 8, remaining in the respective photoperiods until sufficient numbers had been accumulated. Surgery was performed under pentobarbitone sodium anaesthesia. Animals were killed by decapitation and the testes weighed. Pituitary glands, homogenized in $0.5 \mathrm{ml}$ sodium phosphate buffer $(0.05 \mathrm{M}, \mathrm{pH} 7.5)$, and the trunk blood plasma were stored at $-20^{\circ} \mathrm{C}$ until assayed for LH and FSH (Exp. 1), or FSH only (Exps 2 and 3).

\section{Experiment 1: the long-day response of intact males}

In two experiments of identical design sexually mature male hamsters, held in long days from birth, were moved to short days at 35-60 days of age to induce testicular regression. After 50 short days the now sexually immature animals were returned to long days to restimulate testicular growth, and groups (pooled N) were killed after 0 (16), 1 (13), 2 (15), 3 (11), 5 (8), 7 (7), 10 (7), 14 (7), 21 (7), 28 (8), 35 (8), 42 (6), 49 (7) and 56 (7) long days. Due to insufficient volumes of plasma the number of samples assayed for LH per time point were, respectively, 13, $10,14,11,5,5,6,7,7,7,3,6,6$ and 0 . Separate statistical analyses were performed on the data from Days 0-3 and 3-56 to maintain variance homogeneity.

\section{Experiment 2: the long-day response of hamsters castrated when in short days}

One group of male hamsters was raised in short days until 10-50 days old and then exposed to 35 long days to induce testicular growth. In a second group hamsters were raised in long days 
until 25-50 days old. These initial differences in the photoperiodic history of the animals did not affect the outcome of the subsequent experimental manipulation and data from the two groups were pooled. Testicular regression was next induced by moving the animals to short days for 35 or 50 days. At this stage 13 of the animals were killed and about half of the remainder castrated. After a further 35 short days, 9 intact and 12 castrated hamsters were killed. The rest were then moved to long days and killed 35 days later ( 8 intact, 9 castrated).

\section{Experiment 3: the short-day response of hamsters castrated in long days}

Sexually immatures males were accumulated in one group by maintenance in short days from birth until 50-100 days old, and in a second group by exposure to 35 short days after maintenance in long days from birth until 30-70 days of age. These initial differences in treatment did not affect the outcome of the experiment and data were pooled. After the initial period of exposure to short days, the animals were transferred to long days to induce testicular growth and 11 hamsters were killed after 35 or 42 days. Half of the remaining animals were castrated, and 35 days later 10 intact and 10 castrated animals were killed. The rest (14 intact, 14 castrated) were transferred to short days and killed 35 days later.

\section{Radioimmunoassays}

Plasma and pituitary FSH were measured using a micromodification of the NIAMDD rat FSH kit with standard FSH-RP-1, and plasma and pituitary LH by the ovine-ovine assay of Niswender, Midgley, Monroe \& Reichert (1968) using rat standard LH-RP-1. Both assays have been validated for use in the golden hamster (Blake, Norman \& Sawyer, 1973; Berndtson \& Desjardins, 1974); serial dilutions of pituitary homogenates and plasma from intact and castrated Djungarian hamsters gave curves parallel to the standards in both assays. Inter-assay coefficients of variation (s.d./mean) were determined by the inclusion of samples from a plasma pool in each assay, and were $24 \%$ for LH (4 assays) and $19 \%$ for FSH ( 5 assays). Intra-assay coefficients of variation, measured by including 8 pool samples in an LH assay and in an FSH assay, were, respectively, 10 and 4\%. For Exp. 1, plasma and pituitary FSH were measured in 3 assays each, pituitary LH in 2 assays and plasma LH in 1. In Exps 2 and 3, pituitary FSH was measured in.1 assay and plasma FSH in 2 assays. In most instances when data from different assays were pooled, samples from one were assayed in the next as a check additional to the pool samples included in all assays. When there was insufficient plasma to allow repeated assay, titres in samples assayed separately but from the same stage of the experiment were compared to provide verification additional to the plasma pool samples.

\section{Statistical analyses}

Analyses of variance were used throughout. Data from castrated animals in Exps 2 and 3 were combined for analysis.

\section{Results}

\section{Experiment 1: long-day response of intact males}

Changes in testicular weight and plasma and pituitary FSH and LH following photostimulation are shown in Text-fig. 1. After 50 short days these values were minimal. The first signs of testicular growth occurred after 5 long days with testicular weight being significantly greater than on Day $0(P<0.01)$. There then followed a steady increase until a maximum was reached in about 1 month. 


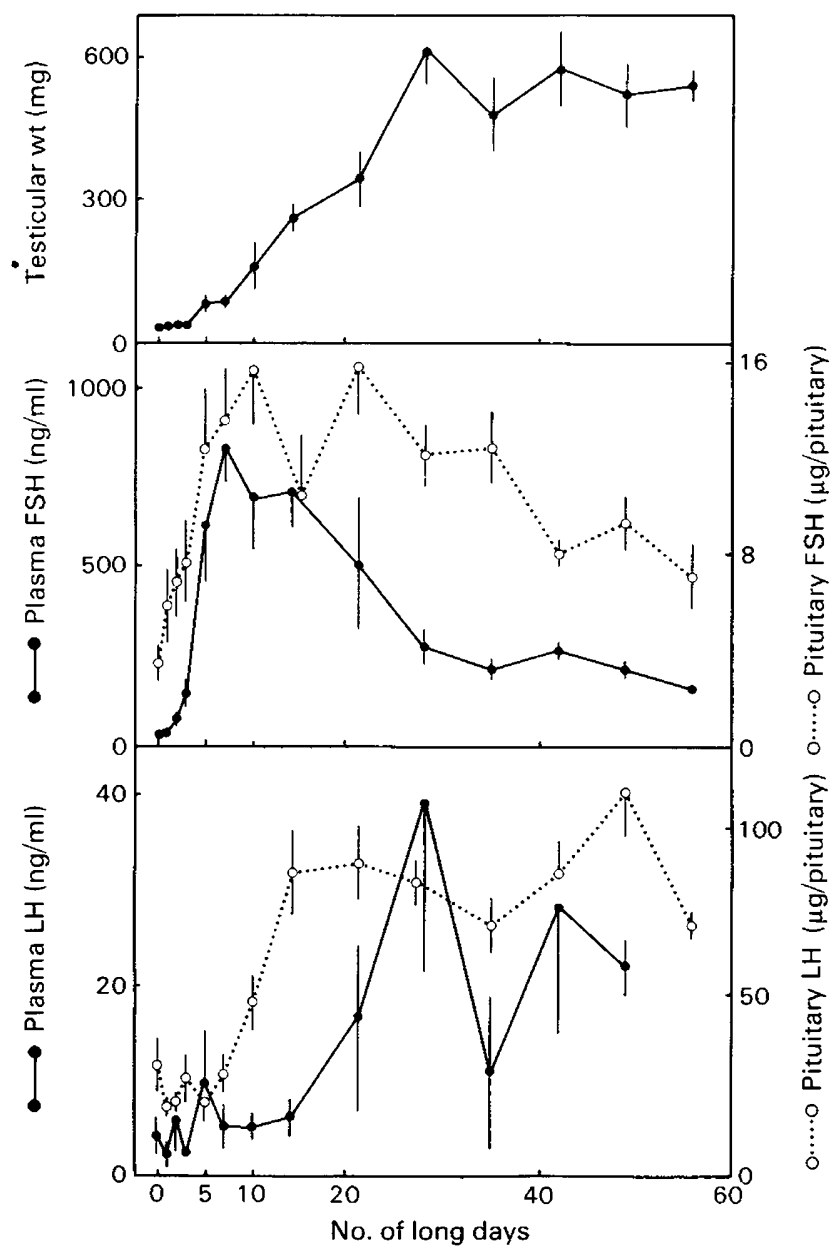

Text-fig. 1. Mean \pm s.e.m. values for testicular weight and concentrations of plasma and pituitary LH and FSH in male Djungarian hamsters after transfer from short to long days. The numbers of animals at each time are given in 'Materials and Methods'.

Plasma FSH concentration was significantly higher after 3 long days $(P<0.01)$, and increased rapidly to reach a peak some 25 -fold greater after 7-14 days. FSH titres then declined significantly over the next 2 weeks to reach a steady state of about $200 \mathrm{ng} / \mathrm{ml}$ at sexual maturity. This was maintained until the experiment ended at 56 days. The changes in pituitary FSH content were generally similar to those seen in the plasma, the content increasing rapidly following photostimulation ( $P<0.01$ after 5 days), reaching peak levels and then declining by Day $56(P<0.05$ compared with peak values on Days 10 and 21$)$.

In contrast with FSH, plasma LH concentrations showed no significant changes until 21 days of photostimulation when the mean level was increased $(P<0.05)$. Plasma levels remained high although the large standard errors (Text-fig. 1) indicated considerable individual variation. Changes in pituitary LH content were more clear-cut. The first significant increase was found after 10 long days $(P<0.01)$ and the level was high and steady from 14 days onwards.

\section{Experiment 2: long-day response of hamsters castrated in short days}

The results are summarized in Table 1 . After 35-50 short days intact hamsters were still undergoing testicular regression; plasma FSH levels and testicular weight declined further after 
another 35 short days $(P<0.05)$. Castration of hamsters after $35-50$ short days led to enormously increased titres of plasma FSH 35 days later, reaching 28 times the level in the intact controls with fully regressed testes, even though the animals remained in a non-stimulatory photoperiod. A substantial difference was also observed in the pituitary FSH content of these short-day castrated hamsters.

Table 1. Mean \pm s.e.m. (n) of plasma and pituitary FSH concentrations in intact and castrated Djungarian hamsters after maintenance in short days and after subsequent transfer to long days

\begin{tabular}{|c|c|c|c|c|}
\hline Animals & $\begin{array}{l}\text { Photoperiod } \\
\text { (no. of days) }\end{array}$ & $\begin{array}{c}\text { Plasma FSH } \\
\text { (ng/ml) }\end{array}$ & $\begin{array}{c}\text { Pituitary FSH } \\
(\mu \mathrm{g} / \text { pituitary) }\end{array}$ & $\begin{array}{l}\text { Testicular } \\
\text { wt (mg) }\end{array}$ \\
\hline $\begin{array}{l}\text { Intact } \\
\text { males }\end{array}$ & $\begin{array}{l}\text { Short }(35-50) \\
\text { Short }(70-85) \\
\text { Long }(35)\end{array}$ & $\begin{array}{r}{ }^{\mathrm{cd}} 102 \pm 27(13) \\
\text { ac } 26 \pm 8(9) \\
\text { ad } 199 \pm 32(8)\end{array}$ & $\begin{array}{c}6.7 \pm 1.8(6) \\
c^{2} 4.3 \pm 0.8(9) \\
{ }^{c} 11.7 \pm 2.4(8)\end{array}$ & $\begin{aligned} \text { ac } 222 & \pm 60(13) \\
\text { bc } 34 & \pm 4(9) \\
\text { ab } 517 & \pm 71(8)\end{aligned}$ \\
\hline $\begin{array}{c}\text { Castrated } \\
\text { males }\end{array}$ & $\begin{array}{l}\text { Short (70-85) } \\
\text { Long (35) }\end{array}$ & $\begin{aligned} & \mathrm{a} 723 \pm 154(12) \\
& \mathrm{a} 1585 \pm 89(9)\end{aligned}$ & $\begin{array}{l}17 \cdot 7 \pm 2 \cdot 3(11) \\
18 \cdot 0 \pm 1 \cdot 3(9)\end{array}$ & \\
\hline
\end{tabular}

Values within columns which have the same superscript letter are significantly different (a, b: $P<0.01$; c, d: $P<0.05$ ).

Photostimulation of intact and castrated hamsters by transferring them to long days increased FSH secretion in both groups. The change in the intact males was much as in Exp. 1 (see Text-fig. 1 and Table 1$)$ and testicular weight increased markedly $(P<0.01)$. Plasma FSH values in the photostimulated castrated hamsters were double those of hamsters in short days ( $P$ $<0.01$ ). This change was not accompanied by an alteration in the FSH content of the pituitary gland.

\section{Experiment 3: short-day response of hamsters castrated in long days}

Testicular weights and the changes in pituitary and plasma FSH contents are shown in Table 2. In intact animals levels of pituitary and plasma FSH were high and the testes fully grown when sampled after 35-42 and 70-77 long days (see Table 2 and Text-fig. 1). After 35 short days both pituitary content and plasma FSH concentration were reduced significantly $(P<$ 0.05 ), although the testes had not yet regressed. Castration after 35-42 long days followed by maintenance on 14L:10D led to a marked increase in both plasma and pituitary FSH. The levels were significantly greater than in intact long-day hamsters but were not different from those in hamsters castrated when in short days and then moved to long days $(P>0.05$, see Tables 1 and 2). Transfer of long-day castrated hamsters to $9 \mathrm{~L}: 15 \mathrm{D}$ caused a significant fall in plasma FSH

Table 2. Mean \pm s.e.m. $(n)$ of plasma and pituitary FSH concentration in intact and castrated Djungarian hamsters after maintenance in long days and after subsequent transfer to short days

\begin{tabular}{|c|c|c|c|c|}
\hline Animals & $\begin{array}{l}\text { Photoperiod } \\
\text { (no. of days) }\end{array}$ & $\begin{array}{c}\text { Plasma FSH } \\
\text { (ng/ml) }\end{array}$ & $\begin{array}{c}\text { Pituitary FSH } \\
(\mu \mathrm{g} / \text { pituitary })\end{array}$ & $\begin{array}{l}\text { Testicular } \\
\text { wt (mg) }\end{array}$ \\
\hline Intact males & $\begin{array}{l}\text { Long }(35-42) \\
\text { Long }(70-77) \\
\text { Short }(35)\end{array}$ & $\begin{array}{l}{ }^{c} 190 \pm 31(11) \\
{ }^{d} 183 \pm 40(10) \\
{ }^{c d} 80 \pm 21(14)\end{array}$ & $\begin{array}{c}\mathrm{c} 8.4 \pm 0.9(10) \\
{ }^{\mathrm{d}} 6.9 \pm 1.8(9) \\
\mathrm{cd}_{3} 3.4 \pm 0.6(12)\end{array}$ & $\begin{array}{l}655 \pm 56(11) \\
728 \pm 61(10) \\
532 \pm 56(14)\end{array}$ \\
\hline Castrated males & $\begin{array}{l}\text { Long (70-77) } \\
\text { Short }(35)\end{array}$ & $\begin{array}{r}{ }^{\mathrm{c}} 1382 \pm 138(10) \\
\mathrm{c}^{\mathrm{c}} 983 \pm 111(14)\end{array}$ & $\begin{array}{l}18.4 \pm 2.3(9) \\
13.9 \pm 2.0(14)\end{array}$ & \\
\hline
\end{tabular}

Values within columns which have the same superscript letter are significantly different $(P<0.05)$. 
concentration within 35 days $(P<0.05)$ to levels not different from those of the short-day castrates in Exp. $2(P>0.05$, see Tables 1 and 2$)$, but still very much higher than in intact hamsters on short days. Pituitary FSH content did not change.

\section{Discussion}

The first experiment confirms previous observations that photoperiod is important in regulating testicular function in Djungarian hamsters (Figala et al., 1973; Hoffmann, 1973, 1978): after 50 short days the testes weighed about $30 \mathrm{mg}$ and this increased to about $600 \mathrm{mg}$ after 28 long days. The onset of testicular growth was rapid, nearly as fast as in quail (Nicholls, Scanes \& Follett, 1973), and a significant increase in weight had occurred after 5 long days. The new data in Exp. 1 were, however, concerned particularly with the photoinduced changes in FSH and LH secretion, the former proving the more useful as an indicator of testicular development. Plasma FSH was significantly increased after 3 long days and the pituitary content was elevated after 5 days. Over the next week the changes in FSH secretion were great and levels increased nearly 10 -fold. Presumably, such high rates of secretion stimulated the rapid spermatogenic and weight changes in the testes. Later, plasma FSH decreased significantly, as did pituitary content, to reach a lower set level of about $200 \mathrm{ng} / \mathrm{ml}$ in mature animals. Very similar changes in FSH secretion are seen in male Djungarian hamsters undergoing sexual maturation when raised from birth in long days, as well as in photostimulated Soay rams, Japanese quail and golden hamsters, the initial phase of high FSH output falling away as the animals mature (Lincoln, Peet \& Cunningham, 1977; Follett \& Maung, 1978; Matt \& Stetson, 1980; Yellon \& Goldman, 1980). The cause of this decrease may well be sex steroid feedback although the fact that LH is not affected to the same extent might be evidence for the involvement of an inhibin. In contrast with FSH, changes in plasma LH concentration during long days were much slower and never entirely convincing. The pituitary content, however, did alter after 10 long days, implying that there might have been relatively early changes in the plasma levels which were obscured by factors such as episodic secretion. In quail the LH changes are clear cut (e.g. Follett \& Maung, 1978) but in many other mammals it is difficult to see obvious increases after photostimulation (Lincoln et al., 1977).

Despite the fast testicular development in Djungarian hamsters kept in long days no significant changes in plasma FSH were detectable until 3 days had passed, by which time 6 of 11 animals had plasma FSH values of $>100 \mathrm{ng} / \mathrm{ml}$. This is too slow a response for many critical experiments into the investigation of certain aspects of the photoperiodic mechanism (see Follett et al., 1977).

In the second part of the study (Exps 2 and 3 ) the effects of castration combined with various photoperiodic treatments were compared with the responses of intact hamsters. Castration of males undergoing testicular regression during short days led to marked increases in plasma and pituitary FSH, indicating that even in short days gonadotrophin secretion is considerably inhibited by negative feedback in intact animals. This is in contrast with golden hamsters in which castration after exposure to short days leads to an initial increase in gonadotrophin secretion which is soon suppressed or, as in birds such as the quail, to little or no immediate elevation of plasma FSH and LH if the gonads are fully regressed (Gibson et al., 1975; Turek et al., 1975; Urbanski \& Follett, 1982; Urbanski \& Simpson, 1982). In other birds (e.g. canary: Nicholls \& Storey, 1976) and in the Soay ram (Lincoln \& Short, 1980) gonadotrophins do increase slightly when non-photostimulated animals are castrated. The transfer of castrated Djungarian hamsters with high levels of FSH secretion from short to long days led to a further increase in hormone output. The absolute size of this increase (about $700 \mathrm{ng} / \mathrm{ml}$ ) was much the same as the initial change following castration under short days. The importance of photoperiod in determining the size of the castration response was further suggested in Exp. 3 in which 
sexually mature hamsters in long days were castrated and, after the response had developed, transferred to short days. Three points emerge from the two experiments. (1) The levels of circulating FSH in castrated hamsters in long days were identical regardless of whether they had been castrated when in short days or long days. (2) FSH levels decreased significantly (by about $400 \mathrm{ng} / \mathrm{ml}$ ) following the movement of castrated hamsters from long to short daylengths. (3) The FSH level in castrated hamsters in short days was similar regardless of their photoperiodic history. Overall, the experiments indicate that photoperiod can alter gonadotrophin secretion independently from the effects of steroid feedback. It might be argued that extragonadal steroids might act to suppress FSH secretion during short days because of some photoperiodically induced hypersensitivity to negative feedback, but this seems unlikely in view of results with golden hamsters (Bittman \& Goldman, 1979; Ellis \& Turek, 1980). In conclusion, therefore, it is clear that in Djungarian hamsters kept in long and short daylengths the testes exercise considerable negative feedback, but in their absence gonadotrophin levels can be driven photoperiodically. It is necessary, then to invoke a mechanism other than changes in feedback sensitivity to explain how photoperiod modulates gonadotrophin secretion; whether or not sensitivity changes take place at all remains a moot point.

We are indebted to Mrs Doreen Bond for breeding the hamsters, to Mrs Judith Pocock for performing some of the assays, and to Dr G. D. Niswender and Dr L. E. Reichert, as well as to the NIAMDD, for immunoassay materials.

\section{References}

Berndtson, W.E. \& Desjardins, C. (1974) Circulating LH and FSH levels and testicular function in hamsters following light deprivation and subsequent photoperiodic stimulation. Endocrinology 95, 195205.

Bittman, E.L. \& Goldman, B.D. (1979) Serum levels of gonadotrophins in hamsters exposed to short photoperiods: effects of adrenalectomy and ovariectomy. J. Endocr. 83, 113-118.

Blake, C.A., Norman, R.L. \& Sawyer, C.H. (1973) Validation of an ovine-ovine LH radioimmunoassay for use in the golden hamster. Biol. Reprod. 8, 299-305.

Brackmann, M. \& Hoffmann, K. (1977) Pinealectomy and photoperiod influence testicular development in the Djungarian hamster. Naturwissenschaften 64 , $341-342$.

Davies, G.J. \& Meyer, R.K. (1973) Seasonal variation in LH and FSH of bilaterally castrated snowshoe hares. Gen. comp. Endocr. 20, 61-68.

Ellis, G.B. \& Turek, F.W. (1979) Time course of the photoperiodic-induced changes in sensitivity of the hypothalamo-pituitary axis to testosterone feedback in male castrated hamsters. Endocrinology 104, $625-630$.

Ellis, G.B. \& Turek, F.W. (1980) Photoperiodic regulation of serum luteinizing hormone and folliclestimulating hormone in castrated and castratedadrenalectomized male hamsters. Endocrinology 106, 1338-1344.

Figala, J., Hoffmann, K. \& Goldau, G. (1973) Zur Jahresperiodik beim Dsungarischen Zwerghamster Phodopus sungorus Pallas. Oecologia 12, 89-118.

Follett, B.K. \& Maung, S.L. (1978) Rate of testicular maturation, in relation to gonadotrophin and testosterone levels, in quail exposed to various artificial photoperiods and to natural daylengths. $J$. Endocr. 78, 267-280.

Follett, B.K., Davies, D.T. \& Gledhill, B. (1977) Photoperiodic control of reproduction in Japanese quail: changes in gonadotrophin secretion on the first day of induction and their pharmacological blockade. J. Endocr. 74, 449-460.

Freedman, L.J., Garcia, M.C. \& Ginther, O.S. (1979) Influence of photoperiod and ovaries on seasonal reproductive activity in mares. Biol. Reprod. 20 , 567-574.

Gaston, S. \& Menaker, M. (1967) Photoperiodic control of hamster testis. Science, N.Y. 158, 925-928.

Gibson, W.R., Follett, B.K. \& Gledhill, B. (1975) Plasma levels of luteinizing hormone in gonadectomized Japanese quail exposed to short or long daylengths. J. Endocr. 64, 87-101.

Goodman, R.L. \& Karsch, F.J. (1980) Control of seasonal breeding in the ewe: Importance of changes in responses to sex-steroid feedback. Prog. Reprod. Biol. 5, 102-133.

Hoffmann, K. (1973) The influence of photoperiod and melatonin on testis size, body weight, and pelage colour in the Djungarian hamster (Phodopus sungorus). J. comp. Physiol. 85, 267-282.

Hoffimann, K. (1974) Testicular involution in short photoperiods inhibited by melatonin. Naturwissenschaften 61, 364-365.

Hoffmann, K. (1978) Effecıs of short photoperiods on puberty, growth and moult in the Djungarian hamster (Phodopus sungorus). J. Reprod. Fert. 54, 29-35. 
Hoffmann, K. (1981) The role of the pineal gland in the photoperiodic control of seasonal cycles in hamsters. In Biological Clocks in Seasonal Reproductive Cycles, pp. 237-250. Eds B. K. Follett \& D. E. Follett. Wright, Bristol.

Hoffmann, K. \& Küderling, I. (1975) Pinealectomy inhibits stimulation of testicular development by long photoperiods in a hamster (Phodopus sungorus). Experientia 31, 122-123.

Hoffmann, K. \& Küderling, I. (1977) Antigonadal effects of melatonin in pinealectomized Djungarian hamsters. Naturwissenschaften 64, 339-340.

Legan, S.J., Karsch, F.J. \& Foster, D.L. (1977) The endocrine control of seasonal reproductive function in the ewe: a marked change in the response to the negative feedback action of estradiol on luteinizing hormone secretion. Endocrinology 101, 818-824.

Lincoln, G.A. \& Kay, R.N.B. (1979) Effects of season on the secretion of $\mathrm{LH}$ and testosterone in intact and castrated red deer stags (Cervus elaphus). J. Reprod. Fert. 55, 75-80.

Lincoln, G.A. \& Short, R.V. (1980) Seasonal breeding, nature's contraceptive. Recent Prog. Horm. Res. 36, $1-52$.

Lincoln, G.A., Peet, M.J. \& Cunningham, R.A. (1977) Seasonal and circadian changes in the episodic release of follicle-stimulating hormone, luteinizing hormone and testosterone in rams exposed to artificial photoperiod. J. Endocr. 72, 337-349.

Matt, K.S. \& Stetson, M.H. (1980) Comparison of serum hormone titres in golden hamsters during testicular growth induced by pinealectomy and photoperiodic stimulation. Biol. Reprod. 23, 893898.

Nicholls, T.J. \& Storey, C.R. (1976) The effects of castration on plasma LH levels in photosensitive and photorefractory canaries (Serinus canarius). Gen. comp. Endocr. 29, 170-174.

Nicholls, T.J., Scanes, C.G. \& Follett, B.K. (1973) Plasma and pituitary luteinizing hormone in Japanese quail during photoperiodically induced gonadal growth and regression. Gen. comp. Endocr. 21, 84-88.

Niswender, G.D., Midgley, A.R., Jr, Monroe, S.E. \& Reichert, L.E., Jr (1968) Radioimmunoassay for rat luteinizing hormone with antiovine LH serum and ovine $\mathrm{LH}^{-131} \mathrm{I}$. Proc. Soc. exp. Biol. Med. 128, 807-811

Pelletier, J. \& Ortavant, R. (1975) Photoperiodic control of $\mathrm{LH}$ release in the ram. I. Influence of increasing and decreasing light photoperiods. Acta endocr. Copenh. 78, 435-441.

Turek, F.W. (1977) The interaction of the photoperiod and testosterone in regulating serum gonadotrophin levels in castrated male hamsters. Endocrinology 101, 1210-1215.

Turek, F.W., Elliott, J.A., Alvis, J.D. \& Menaker, M. (1975) The interaction of castration and photoperiod in the regulation of hypophyseal and serum gonadotrophin levels in male golden hamsters. Endocrinology 96, 854-860.

Urbanski, H.F. \& Follett, B.K. (1982) Photoperiodic modulation of gonadotrophin secretion in castrated Japanese quail. J. Endocr. 92, 73-83.

Urbanski, H.F. \& Simpson, S.M. (1982) Photoperiodic suppression of gonadotrophin secretion in castrated male hamsters. J. Reprod. Fert. 66, 299-303.

Yellon, S.M. \& Goldman, B.D. (1980) Short days inhibit the developmental pattern of FSH and prolactin in the male Djungarian hamster, Phodopus sungorus. Biol. Reprod. 22 (Suppl. 1), p. 88A, Abstr.

Received 30 November 1981 